\title{
Soil Erosion Assessment of the Poyang Lake Basin, China: Using USLE, GIS and Remote Sensing \\ Yuan $\mathrm{LF}^{1,2}$, Yang $\mathbf{G S}^{2}$, Zhang $\mathbf{Q F}^{3^{*}}$ and $\mathbf{L i} \mathrm{HP}^{2}$ \\ ${ }^{1}$ USDA-ARS, National Soil Erosion Research Laboratory, 275 S. Russell Street, West Lafayette, IN 47907, United States of America \\ ${ }^{2}$ Key Laboratory of Watershed Geographic Sciences, Nanjing Institute of Geography and Limnology, Chinese Academy of Sciences, Nanjing 210008, China \\ ${ }^{3}$ College of Natural Resources and Environment, Northwest A\&F University, Yangling 712100, China
}

*Corresponding author: Zhang QF, College of Natural Resources and Environment, Northwest A\&F University, Yangling 712100, China, Tel: +86-29-87080055; E-mail: zhqf@nwsuaf.edu.cn

Rec date: May 09, 2016; Acc date: Jun 17, 2016; Pub date: Jun 24, 2016

Copyright: (c) 2016 Yuan LF, et al. This is an open-access article distributed under the terms of the Creative Commons Attribution License, which permits unrestricted use, distribution, and reproduction in any medium, provided the original author and source are credited.

\begin{abstract}
Soil erosion is one of the most critical eco-environmental issues in the Poyang Lake basin, China. The purpose of this study is to discover the spatial pattern of soil erosion, and predict soil loss and sediment yield, and evaluate soil loss impacts on main reservoirs by using Universal Soil Loss Equation (USLE), GIS and Remote Sensing (RS). Firstly, five erosion factors including rainfall erosivity $(R)$, soil erodibility $(K)$, topographic factor (LS), cover and management factor $(C)$, and conservation supporting practice factor $(P)$ were calculated and analyzed, respectively. Secondly, annual soil erosion and its spatial distribution were evaluated, and sediment yield was subsequently predicted. Next, soil erosion was classified into five erosion categories according to Industry Standard of Water Resources of China. Then, the relationship among soil erosion, landform and land use and land cover (LULC) were analyzed. Finally, the influence of soil erosion on main reservoirs in the basin were assessed. The result showed that:
\end{abstract}

$28.3 \%$ of the total watershed area appears soil loss; the average annual soil loss amount is approximate $2.7 \times$ $10^{7} \mathrm{t}$; soil erosion modulus ranged from 0 to $394.8 \mathrm{t} / \mathrm{ha} / \mathrm{y}$, with a mean value of $1.82 \mathrm{t} / \mathrm{ha} / \mathrm{y}$.

$71.7 \%$ of the watershed area are undergoing minimal erosion, primarily appear in surrounding the lake area, both sides of river valley and plains of five main rivers; $24.1 \%$ of the watershed area are undergoing low erosion, mainly found in the west, east, central hilly and mountain areas; $3.4 \%$ of the watershed area was observed moderate soil erosion; $0.83 \%$ of the watershed area are undergoing high, very high and extreme soil erosion, which located in the northeastern and northwestern corner, and the upstream of the Ganjiang river and Fuhe river sub-watershed.

Low and moderate soil erosion most frequently occurred at the plains and hills zone in this basin.

Soil loss happens on needleleaved forest, rainfed croplands and shrub land use type are greater than that of other LULC types; soil erosion modulus descends on the different land use types, orderly by bare lands, grass lands, shrub lands, rainfed croplands, needleleaved forest, spares vegetation, broadleaved deciduous forest, artificial surface, irrigated croplands and water bodies.

Present main reservoirs are undergoing a big threat from the upstream sediment load, especially as the Qiyi, Da'ao, Qixing and Tuolin reservoir.

Keywords: Soil erosion; Poyang lake basin; USLE; Sediment yield; Reservoirs

\section{Introduction}

Soil erosion is one of the most critical environmental issues because of its adverse economic and ecological influence [1]. Water erosion is the main category of soil erosion, and it removes valuable top soil which is the most productive part of the soil profile for agricultural purpose. The loss of top soil results in lower yield and higher production costs. Moreover, soil erosion leads to the deposition of sedimentation in downstream river channels; further raise a riverbed; pollute natural water bodies and reduce a storage capacity of reservoirs. Soil erosion greatly aggravates the risk of floodwater, drought and landslide, and causes the degeneration of ecoenvironments $[2,3]$.

In fact, soil erosion has become one of the most crucial ecoenvironmental issues in China [4]. According to results of the 2nd national soil erosion remote sensing survey, the area of soil loss was $3.56 \times 10^{6} \mathrm{Km}^{2}$ in 2003 , accounting for $37.1 \%$ of the total land area of China, in which the area of water erosion reached at $1.65 \times 10^{6} \mathrm{Km}^{2}$, accounting for $46.3 \%$ of the total soil erosion area [5]. The overall situation of soil loss is difficult to be controlled at the current developing stage in China. Eco-environment damage often happen after temporarily controls soil erosion in many regions of China. While the conditions of soil erosion were improved in some key management districts, there was overall deterioration [6]. 
Poyang Lake $\left(28^{\circ} 22^{\prime}-29^{\circ} 45^{\prime} \mathrm{N}, 115^{\circ} 47^{\prime}-116^{\circ} 45^{\prime} \mathrm{E}\right)$ is the largest freshwater lake in China. Its water quality is high, and the lake and its surroundings provide rich wetland resources. It has been listed as a hotspot area of biodiversity protection of the International Wetlands. Therefore, the ecological and geographic location of Poyang Lake is significant in China [6]. It has become a national strategy for protecting regional eco-environment and water quality since 2009. However, soil erosion has been the most critical eco-environment problem in the basin $[7,8]$, Soil erosion situation has obviously changed in the basin due to intensive human activity and climate change in the past half-century. For example, in the 1950s, the area of soil loss was $6.78 \%$ of the total land area; in the 1970 s, the figure was $14.79 \%$; in the end of the 1980 s, it was $28.35 \%$; in the 1990 s, it was $21.1 \%$ [9]. In the 2000s, the total area of soil loss is about $3.35 \times 10^{4}$ $\mathrm{Km}^{2}$, accounting for $20.03 \%$ of the total land area [10]. Therefore, the soil erosion problem of the basin has attracted attention of many researchers and some research results concerning soil erosion have been published. Zou et al. [11] assessed the soil erosion risk of the Poyang Lake basin based on Principle Component Analysis and GIS. Shi et al. [9] analyzed the historical and current situation of soil erosion, summarized the characteristic, types and pattern of soil erosion, and analyzed the causes and impact factors of soil loss. Ma et al. [11] reported the spatio-temporal distribution characteristics of rainfall erosivity by using daily precipitation data of 16 meteorological stations during 1957-2008, Mann-Kendall non-parameter test, radial basis functions, statistical interpolation methods and GIS. Fan et al. [12] investigated the influence of land use change on soil erosion across the basin under the help of GIS, RS, and GPS, and quantified the spatial relationship between land use change and soil erosion through using the transitional matrix of land use change and the soil erosion intensity index. Lu et al. [13] estimated the amount of soil erosion in the basin using USLE, GIS and remote sensing, and calculated the five erosion factors value of USLE model, and compared the pattern of soil erosion between 199 and 200. Yuan et al. [14] indicated the risk of soil erosion in the basin based on USLE and GIS, calculated erosion impact factors in USLE model, and revealed the spatial pattern of soil erosion risk. The mentioned above studies can help people better understand the soil erosion issue in the Poyang Lake basin. Few of above studies, however, analyzed sediment yield of the basin and the influence of soil loss on main reservoirs. Therefore, this study first assessed soil loss impact on main reservoirs of the Poyang Lake basin, it would be a good reference to future construction of reservoirs, and is helpful to protect regional eco-environment in Poyang Lake basin.

To evaluate soil loss and to develop optimal soil erosion management plans, many soil erosion models, such as Universal Soil Loss Equation (USLE) [15], Soil and Water Assessment Tool (SWAT) (Arnold et al.), Water Erosion Prediction Project (WEPP) [16], and European Soil Erosion Model (EUROSEM) [17,18], have been developed and used over the years. These soil erosion models can be divided into two types according models inner running mechanism: empirically and physically. Because the latter require many input parameters and are not well verified, empirically based models are more popular in soil erosion estimation [18]. Compared to other empirically based models, USLE is the most prevalent method for assessing soil loss because its input data are easier available and the model is relatively easy to use $[18,19]$. It can predict the long-term, average annual erosion rate on a field slope [15]. Besides, GIS makes soil erosion evaluation cost-efficient and visual its spatial distribution feasible. Thus, USLE and its adapted versions have been widely applied to worldwide soil erosion assessment in GIS environment [13,14,20-22].

This paper took the Poyang Lake basin as a case, focusing on the qualitative assessment and spatial pattern of soil erosion and its impact on main reservoirs. Five soil erosion factors were calculated and analyzed in GIS environment, annual soil loss and its spatial distribution were descriptive; Soil erosion was classified into five intensity categories, and soil loss amount and its pattern on different landform, LULC, and the upstream sediment yield of reservoirs were calculated and analyzed. The research results is helpful to identify soil erosion critical zone and allow the development of site-specific erosion management measures in high erosion risk areas to enhance environmental protection of the Poyang Lake basin in the future.

\section{Materials and Methods}

\section{Study area}

The Poyang Lake basin $\left(24^{\circ} 29^{\prime}-30^{\circ} 3^{\prime} \mathrm{N}, 113^{\circ} 42^{\prime}-118^{\circ} 36^{\prime} \mathrm{E}\right)$ is located at the middle reaches and southern bank of the Yangtze River (Figure 1). The northern Poyang Lake basin is an area of low elevation and contains the Poyang Lake. Mountains surround northern lowland region, and the five major rivers flow into Poyang Lake, including the Gangjiang, Fuhe, Xinjiang, Raohe and Xiushui River. They drain through the Hukou hydrological station into the Yangtze River, the biggest river in China, and thus form an integral Poyang Lake catchment system [23]. The total drainage area of the basin is $1.62 \times$ $10^{5} \mathrm{Km}^{2}$, accounting for $9 \%$ of the area of the Yangtze River basin and $96.85 \%$ of the land area of Jiangxi Province [24]. The topography in the basin is complex, including mountains, hills, alluvial plains, water bodies, etc. The basin is mainly composed of eight land use types, such as forest, cropland, plantation, grassland, water body, wetlands, builtup and barren land. The soil types of the basin include Red earths, Paddy soils, Yellow earths, Purplish soils, and other small soil groups. The basin belongs to the subtropical monsoon climate zone and has a temperate and humid climate with abundant sunlight. The annual average temperature is 17.9 and the amount of areal average annual precipitation is $1400-1800 \mathrm{~mm}$, of which $50 \%$ mainly concentrate in April-June. Monthly precipitation of the basin increases rapidly from January to June and then decreases sharply. The spatio-temporal distribution of rainfall and runoff in the basin is very uneven, and obviously changes within the annual and inter annual scale, which exhibits distinctly seasonality and regionality. The floodwater and drought disasters of the basin appear frequently [25]. 


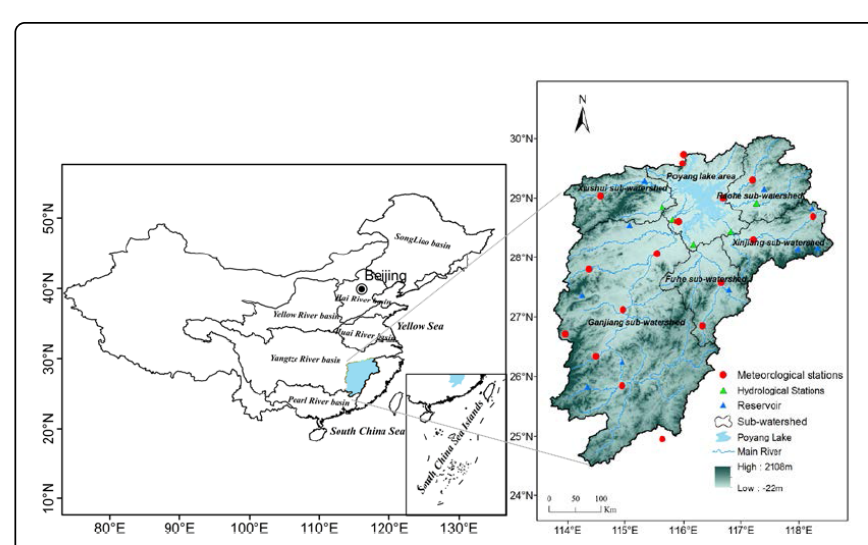

Figure 1: Location of the study area and meteorological stations.

\section{Methods}

USLE quantitatively estimates soil erosion by the following empirical equation [15]:

$$
A=R \times K \times L \times S \times C \times P
$$

Where, $\mathrm{A}$ is the potential long term annual soil loss per unit area ( $\mathrm{t}$ $\left.\mathrm{ha}^{-1}\right), \mathrm{R}$ is the rainfall and runoff erosivity factor $\left(\mathrm{MJ} \mathrm{mm} \mathrm{ha}{ }^{-1}\right), \mathrm{K}$ is soil erodibility factor $\left(\mathrm{t}\right.$ ha $\left.\mathrm{h} \mathrm{ha} \mathrm{h}^{-1} \mathrm{Jm}^{-1}\right), \mathrm{L}$ is slope length factor, $\mathrm{S}$ is slope steepness factor, $\mathrm{C}$ is cover and management factor, and $\mathrm{P}$ is conservation supporting practice factor, $\mathrm{L}, \mathrm{S}, \mathrm{C}$, and $\mathrm{P}$ are all dimensionless.

We only selected the most suitable formulas to calculate USLE model various erosion factors. We mainly considered data availability and feasibility when selecting the formulas for several reasons: 1) the Poyang Lake basin is a large scale, and some observational data are often hard to obtain; 2) the terrain of the basin is complex, accessibility is poor, and it is unrealistic to conduct many field experiments for obtaining model parameters.

\section{Rainfall erosivity factor $(R)$}

The rainfall is a direct driving factor, and it is also the prerequisite condition of soil erosion. The rainfall erosivity factor (R) quantifies the effect of rainfall impact and reflects the amount and rate of runoff associated with precipitation events [22]. The $\mathrm{R}$ factor was derived according to the modified Fournier index due to the lack of daily rainfall intensity records. This index is used widely to estimate the $\mathrm{R}$ factor through monthly rainfall data $[13,26-28]$; it is determined by the ratio between monthly and annual precipitation. Rainfall data was obtained from the China Meteorological Data Sharing Service System (http://cdc.nmic.cn/). Long-term monthly rainfall data covering 1960 to 2008 at 17 rain gauge stations in the basin are used to calculate the $R$ factor by the formula recommended by Arnoldus [18]:

$$
R_{a}=\left[4.17 \times \sum_{i=1}^{12}\left(\frac{p_{i}^{2}}{p}\right)\right]-152
$$

Where, $p_{i}$ is the monthly average rainfall $(\mathrm{mm})$ for the month $i, p$ is the annual average rainfall $(\mathrm{mm})$ and $R_{a}$ represents the annual average rainfall erosivity $\mathrm{R}$ value. The rainfall erosivity map was derived by the Inverse Distance Weighting (IDW) interpolation method in ArcGIS 10 because the influence of rainfall erosivity decreases as distance increases away from the rainfall gauge stations.

\section{Soil erodibility factor $(K)$}

The sensitivity of soil agent to erosion is called as soil erodibility factor K. This factor indicates vulnerability of soil to detachment and transport driven by raindrops and runoff and is defined as the rate of soil loss per the rainfall erosion index unit as measured on a standard plot [15]. It is a mathematic function of the percentage of silt, coarse sand, soil structure, permeability of soil and the percentage of organic matter. The $\mathrm{K}$ factor is based on the soil types. It is not easy to directly measure the $\mathrm{K}$ value of soil in the basin because of the influence of research scale and financial cost. This study determined the $\mathrm{K}$ value by the 1:4,000,000 scale soil map of the Poyang Lake basin that comes from the Second National Soil Survey of China in 1995, which was provided by the Institute of Soil Science, Chinese Academy of Sciences, using the values suggested by $\mathrm{Yu}$ et al. [29] and $\mathrm{Lu}$ et al. [13]. The K value map was obtained by assigning these values to the soil map. Eight groups of soil type and the $\mathrm{K}$ values are shown in Table 1.

\begin{tabular}{|l|l|}
\hline Soil types & K value $\left(\mathbf{t ~ h a ~} \mathbf{h ~} \mathbf{h a}^{-1} \mathbf{~} \mathbf{J}^{-1} \mathbf{~} \mathbf{m}^{-1}\right)$ \\
\hline Red earths & 0.030 \\
\hline Red earths soils & 0.029 \\
\hline Yellow earths & 0.025 \\
\hline Yellow-brown earths & 0.028 \\
\hline Purplish soils & 0.045 \\
\hline Paddy soils & 0.054 \\
\hline Limestone soils & 0.022 \\
\hline Water body & 0.000 \\
\hline
\end{tabular}

Table 1: Soil types and their K values.

\section{Topographic factor (LS)}

The topographic factor LS reflects the combined effect of length (L) and steepness (S) of the slope. The amount of soil erosion increases as the slope length and steepness increases. USLE represents the combined effects of rill and inter-rill erosion. Rill erosion is mainly caused by surface runoff and increases in a downslope direction because the runoff increases in this direction. Inter-rill erosion is caused primarily by raindrop impact. Therefore, the $\mathrm{L}$ factor is greater for those conditions where rill erosion tends to be greater than interrill erosion. Erosion increases with slope steepness (S), in contrast to the $\mathrm{L}$ factor representing the effects of slope length (L), the USLE makes no differentiation between rill and inter-rill erosion in the $S$ factor which computes the effect of slope steepness on soil loss [21]. The DEM has been commonly used to derive topographic characteristics. The LS factor is usually calculated together using DEM as inputting into the equation suggested by Moore and Burch [30,31] as:

$$
\begin{aligned}
& L S=(\text { Flow accumulation } \times \text { Cell size } / 22.13)^{0.4} \\
& \times(\sin \theta / 0.0896)^{1.3}
\end{aligned}
$$

Where, LS is the topographical factor, flow accumulation denotes the accumulated upslope contributing area for a given cell. The cell size 
is $90 \mathrm{~m}$ in this study and $\theta$ is the slope angle in degrees. As USLE is only used to access rill and inter-rill erosion, it is necessary to set the upper limitation of slope length. In this study, the upper limitation of slope length was set as $180 \mathrm{~m}$ (two cell size) which means rill erosion happens in $180 \mathrm{~m}$ slope length. The flow accumulation grid was revised to calculate the LS factor values by the upper limitation of slope length. Shuttle Radar Topography Mission (SRTM) DEM data version 4.1 (http://srtm.csi.cgiar.org/, Nov. 25, 2008) was used to calculate the LS factor [32].

\section{Cover and management factor $(\mathrm{C})$}

Vegetation cover protects soil by dissipating the raindrop energy before reaching the soil surface. The cover and management factor $\mathrm{C}$ represents the effect of soil disturbing activities, plants, crop sequence and the productivity level, soil cover and subsurface bio-mass on soil erosion. It is defined as the ratio of soil loss from crop land under specified conditions to the corresponding clean-tilled continuous fallow [15]. The value of $C$ depends on vegetation type, stage of growth and cover percentage [33]. Higher values of the $C$ factor indicate no cover effect and soil loss comparable to that from a tilled bare fallow, while lower $C$ value means a very strong cover effect resulting in no erosion [34]. The $\mathrm{C}$ value was determined by land cover type (Table 2), referring the values suggested by Lu et al. [13], Yu et al. [29] and Zhu [22]. The LULC data was derived from Globcover 2009 dataset version 2.3 (http://maps.elie.ucl.ac.be/geoportail/), Global Land Cover Project of Europe Space Agency (ESA), with a cell size of $300 \mathrm{~m}$. In this study, the land use classes were allocated $\mathrm{C}$ values without considering influence of seasonal variance and vegetation growth stage.

\begin{tabular}{|l|l|}
\hline LULC types & C value \\
\hline Irrigated croplands & 0.088 \\
\hline Rainfed croplands & 0.31 \\
\hline Broadleaved deciduous forest & 0.003 \\
\hline Needle leaved forest & 0.017 \\
\hline Shrub lands & 0.069 \\
\hline Grass lands & 0.05 \\
\hline Spares vegetation & 0.18 \\
\hline Artificial surface & 0.01 \\
\hline Bare areas & 1 \\
\hline Water bodies & 0 \\
\hline
\end{tabular}

Table 2: $\mathrm{C}$ values for different LULC types.

\section{Conservation supporting practice factor $(P)$}

The conservation supporting practice factor $\mathrm{P}$ is defined as the ratio of soil loss with a support practice like contouring, strip-cropping, or terracing to that with straight-row farming up and down the slope [15]. The values of the $\mathrm{P}$ factor ranges from 0 to 1 , in which the high value is assigned to areas with no conservation practices; the low values correspond to plantation areas with strip and contour cropping. $\mathrm{P}$ factor value was thought to be the most difficult factor to determine and was the least reliable factor in the USLE input factors [35], especially in a large spatial scale. Therefore, this study determined the
$P$ value by the slope, LULC data of the study area (Table 3), and using the values recommended by $\mathrm{Lu}$ et al. [13], Yu et al. [29] and $\mathrm{Li}$ et al. [27]. The slope map (\%) was prepared by DEM and it was merged with LULC data using overlay analysis in ArcGIS. The $\mathrm{P}$ value was then assigned to the merged classes of the different slope ranges. This study used LULC data in 2009 with slope to obtain the P factor because it is hard to calculate the long-term average land use pattern.

\begin{tabular}{|l|l|l|}
\hline LULC types & Slope/\% & P value \\
\hline Water bodies & $0 \sim 330$ & 0 \\
\hline Irrigated croplands & $0 \sim 330$ & 0.05 \\
\hline & $0 \sim 5$ & 0.11 \\
\hline & $5 \sim 10$ & 0.12 \\
\hline Arable lands & $10 \sim 20$ & 0.14 \\
\hline & $20 \sim 30$ & 0.19 \\
\hline & $30 \sim 50$ & 0.25 \\
\hline Forest lands & $>50$ & 0.33 \\
\hline Others & $0 \sim 330$ & 0.8 \\
\hline
\end{tabular}

Table 3: P values for different LULC types and slope range.

\section{Data Preprocessing}

Applying mentioned above methods, all the data were calculated using the Raster Calculator tool in the ArcGIS 10.1. The spatial resolution and coordinate system of the factor layers were consistent with the original data. After generating five impact factor layers, we resampled them into a cell size with $300 \times 300 \mathrm{~m}$ in a uniform coordinate system, and the quantitative output of annual soil erosion was computed by multiplying the $\mathrm{R}, \mathrm{K}, \mathrm{LS}, \mathrm{C}$ and $\mathrm{P}$ factors in ArcGIS10.1. The classification of soil erosion intensity was obtained by the reclassify function in the spatial analysis toolset of ArcGIS.

\section{Results}

\section{USLE model accuracy evaluation}

The sediment delivery ratio (SDR) method was used to verify the accuracy of USLE model output. The ratio of sediment delivered at a given location in the stream system to the gross erosion from the drainage area above that location is the sediment delivery ratio for that drainage area [15]. SDR is the ratio of sediment yield to the total soil loss. The equation may be expressed in non-dimensional terms as:

\section{$\mathrm{SDR}=\mathrm{S}_{\mathrm{y}} / \mathrm{T}(4)$}

Where, $S_{\mathrm{y}}$ is the sediment yield at the watershed outlet or point of interest, and $\mathrm{T}$ is the total soil loss defined as the total eroded sediment on the areas eroding above the watershed outlet or point of interest. In this study, we assume that gully and channel erosion is negligible, and the gross soil loss is equal to the output of USLE model. By using the average annual sediment data observed by hydrological stations, and multiplying USLE model output by the SDR as simulated sediment yield, we calculated absolute error and relative error to evaluate the accuracy of soil erosion data from the USLE model output (Table 4). 


\begin{tabular}{|l|l|l|l|l|}
\hline \multicolumn{6}{|l|}{ Sediment yield (10 $\mathbf{t} / \mathbf{y})$} & $\begin{array}{l}\text { Sun et al. [6] } \\
\text { 1956-2005 }\end{array}$ & $\begin{array}{l}\text { Min et al. [36] } \\
\text { 1956-2005 }\end{array}$ & $\begin{array}{l}\text { Luo et al. [37] } \\
\text { 1956-2008 }\end{array}$ \\
\hline ID & Name & 918 & 916 & 880 \\
\hline 1 & Waizhou & 146 & 143 & 140 \\
\hline 2 & Lijiadu & 216 & 212 & 204 \\
\hline 3 & Meigang & 37 & 99 & 56 \\
\hline 4 & Hushan & 36 & 80 & 36 \\
\hline 5 & Wanjiabu & 36 & 239 & - \\
\hline 6 & Poyang lake area & - & & \\
\hline
\end{tabular}

Table 4: Observed sediment yield of five main hydrological stations.

We analyzed and evaluated the annual sediment yield of the five main hydrological stations from references in Sun et al. [7], Min et al. [36] and Luo et al. [37]. It can be seen that the latter data time series is longer than the former two and matches with the study (Table 4); thus, background data was collected from Luo et al. [37]. In addition, there are few research studies on SDR about the Poyang lake basin. Jing et al. [38] illustrated the average SDR value is 0.54 in the Ganjiang, a largest sub-watershed of the Poyang Lake basin, and there is no clear-cut correlation among sediment yield, soil erosion amount, SDR and watershed area [39]. After considering these reasons, we used 0.54 as an average SDR value for the study area.

As can be seen in Figure 4, the simulated sediment yield is greater than the observed sediment yield at the main four hydrological stations except the Waizhou station. In fact, in references of Sun et al. [6] and Luo et al. [36], the actual drainage area of Hushan hydrological station is only $6374 \mathrm{Km}^{2}$, not including Changjiang river drainage area, and the actual drainage area of the Wanjiabu hydrological station is only $3548 \mathrm{Km}^{2}$, not including the main stream drainage area with the largest reservoir, Tuolin, in the Poyang Lake area; so we consider that the observed sediment yield of both Hushan and Wanjiabu stations is far less than the actual annual sediment yield.

According to the observations mentioned above, and to consider data reliability, three main hydrological stations (Waizhou, Lijiadu and Meigang), where sediment yield data was observed from 1956 to 2008, were selected for the accuracy evaluation. The results of accuracy evaluation showed that absolute error and relative error is $-2.51 \times 10^{6} \mathrm{t}$ and $-28.5 \%$ at Waizhou, $4.0 \times 10^{4} \mathrm{t}$ and $3.1 \%$ at Lijiadu, and $4.0 \times 10^{5} \mathrm{t}$ and $19.7 \%$ at Meigang, respectively. The average relative error is $17.1 \%$ (Table 4). Thus, it was considered that the average annual soil erosion was properly simulated, and the result of USLE model simulation is reliable.

\section{USLE factors analysis}

The annual $\mathrm{R}$ value ranged from 456.6 to 722.3 with a mean of 585.7 MJ mm ha ${ }^{-1}$; the standard deviation is 58.8 . The spatial distribution of $R$ values over the basin is shown in Figure 2(a); the $R$ value generally increased from the southwest to the northeast of this area. Lower $\mathrm{R}$ values were primarily distributed in the southwest, and higher $R$ values were mainly distributed in the northeast and the northern corner. In comparison, the average $\mathrm{R}$ values was generally distributed in the central part. These trends were mainly dependent on the spatial distribution features of the long-term average annual precipitation.

There are eight main soil groups in the study area, and the largest soil group is Red earths. Red earths is widely distributed in the whole basin, and accounting for $40 \%$ of the study area. The second largest soil group is Red earth soils, mainly located in the center, southwest, and northeastern corner of the study area, and accounting for $24 \%$ of the study area. Paddy soils is the third largest soil group, mainly located at both surrounding the lake area and both banks of five main rivers, accounting for $21 \%$ of the study area. $15 \%$ of the study area is comprised of other soil groups, including Yellow earths, Purplish soils, Yellow-brown earths, and Limestone soils. The $\mathrm{K}$ factor ranges from 0 to 0.054 ( $\mathrm{t}$ ha h ha-1 $\mathrm{J}^{-1} \mathrm{~m}^{-1}$ ). Spatial distribution of the $\mathrm{K}$ factor (Figure 2(b)) decreased radiating from the lake area to the surrounding mountain area. Its distribution is generally correlated with the variation of terrain, with the higher $\mathrm{K}$ value appear at the lake area and river valley plains, and the lower $\mathrm{K}$ value happen at the mountain area.

Figure 1 shows the elevation map of the study area. Elevation ranges from $-22 \mathrm{~m}$ to $2108 \mathrm{~m}$, the average elevation is $1075 \mathrm{~m}$. As can be seen in Figure 2(c), the LS factor value varies from 0 to 40.72 , with a mean value of 3.70. The areas with higher LS values are generally located in the mountain areas and the areas with lower LS values is in the lake area and river valley plains.

The $C$ values map (Figure $2(\mathrm{~d})$ ) was produced from LULC data in 2009. The $C$ values ranged from 0 to 1 . The lower $C$ values are found in the mountain areas, where the majority of land is covered by forest. The higher $\mathrm{C}$ values are found around the lake area and river valley plains.

The P values map (Figure 2(e)) was prepare from the LULC data and the slope map. The $\mathrm{P}$ values ranges from 0 to 1 . The lower $\mathrm{P}$ values are found around the lake area and river valley plains, and the higher $P$ values are observed in mountain areas. 
(a)

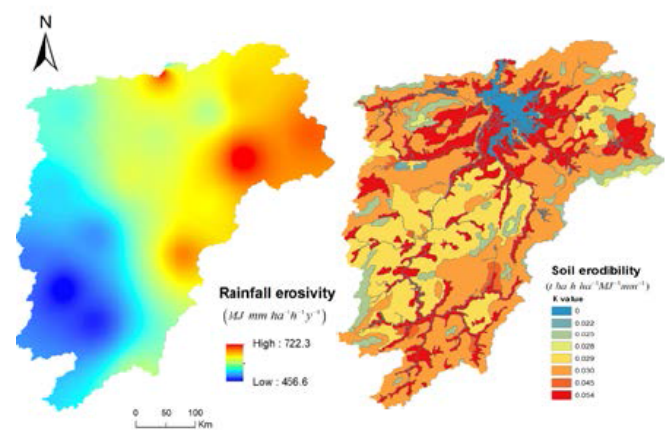

(c)

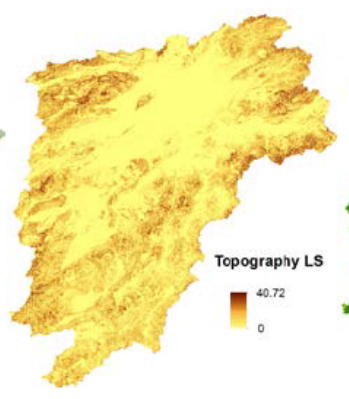

(d)

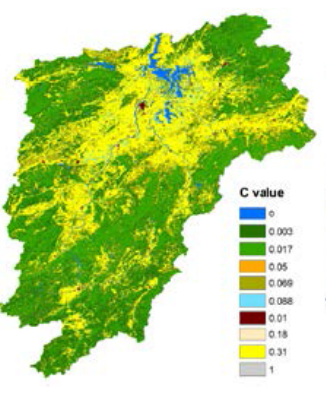

(e)

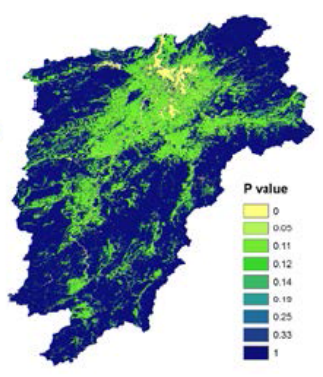

Figure 2: USLE factors: (a) R; (b) K; (c) LS; (d) C; (e) P in the Poyang Lake basin.

\section{Average annual soil erosion and sediment yield}

The annual soil erosion was estimated by incorporating all erosion impact factors. The results show that the amount of the average annual soil loss is $2663 \times 10^{4} \mathrm{t} / \mathrm{y}$ and the average annual sediment yield which fed into the Poyang Lake is $1436 \times 10^{4} \mathrm{t} / \mathrm{y}$ (Table 5). The mean soil erosion modulus is $1.82 \mathrm{t} / \mathrm{ha} / \mathrm{y}$ for the whole basin, the maximum soil erosion modulus is $394.8 \mathrm{t} / \mathrm{ha} / \mathrm{y}$, which located at the northeast of the area and the minimum soil erosion modulus is $0 \mathrm{t} / \mathrm{ha} / \mathrm{y}$ which occurred on water bodies. The pattern of the soil erosion modulus shows that it increases radiately from the Poyang lake area to surrounding the mountain area, the most serious soil erosion occurred primarily in the northeast and northwest, and the upstream area of Ganjiang and Fuhe River (Figure 3 (a)).

\begin{tabular}{|c|c|c|c|c|c|c|c|c|c|c|c|c|}
\hline No. & $\begin{array}{l}\text { Sub- } \\
\text { watershed }\end{array}$ & $\begin{array}{l}\text { Hydrological } \\
\text { stations }\end{array}$ & Area (ha) & $\begin{array}{l}\text { Area } \\
(\%)\end{array}$ & $\begin{array}{l}\text { Mean soil } \\
\text { erosion } \\
\text { modulus } \\
(\mathrm{t} / \mathrm{ha} / \mathrm{y})\end{array}$ & $\begin{array}{l}\text { Max soil } \\
\text { erosion } \\
\text { modulus } \\
(\mathrm{t} / \mathrm{ha} / \mathrm{y})\end{array}$ & $\begin{array}{l}\text { Soil loss } \\
\left(10^{4} t / y\right)\end{array}$ & $\begin{array}{l}\text { Soil } \\
\text { erosion } \\
\text { Area (\%) }\end{array}$ & $\begin{array}{l}\text { Simulated } \\
\text { sediment } \\
\text { yield } \quad\left(10^{4}\right. \\
\text { t/y) }\end{array}$ & $\begin{array}{l}\text { Observed } \\
\text { sediment } \\
\text { yield } \quad\left(10^{4}\right. \\
\mathrm{t} / \mathrm{y})\end{array}$ & $\begin{array}{l}\text { Absolute } \\
\text { error }\left(10^{4}\right. \\
t / y)\end{array}$ & $\begin{array}{l}\text { Relative } \\
\text { error (\%) }\end{array}$ \\
\hline 1 & Ganjiang & Waizhou & 8094800 & 50.1 & 1.44 & 259.8 & 1168 & 43.9 & 631 & 880 & -251 & -28.5 \\
\hline 2 & Fuhe & Lijiadu & 1581100 & 9.8 & 1.69 & 165.4 & 267 & 10 & 144 & 140 & 4 & 3.1 \\
\hline 3 & Xinjiang & Meigang & 1553500 & 9.6 & 2.91 & 394.8 & 452 & 17 & 244 & 204 & 40 & 19.7 \\
\hline 4 & Raohe & Hushan & 1486000 & 3.9 & 1.78 & $\begin{array}{l}274 . \\
8\end{array}$ & 265 & 10 & 143 & 56 & - & - \\
\hline 5 & Xiushui & Wanjiabu & 1446200 & 2.2 & 2.16 & 181.4 & 312 & 11.7 & 169 & 36 & - & - \\
\hline \multirow[t]{2}{*}{6} & Poyang Lake & - & 2058500 & 24.4 & 0.96 & 167.1 & 198 & 7.4 & 107 & - & - & - \\
\hline & Total & - & 16220000 & 100 & - & - & 2663 & 100 & 1436 & 1316 & - & - \\
\hline
\end{tabular}

Note: Sub-watershed area was extracted from SRTM DEM by hydrological analysis method in ArcGIS. The value of SDR is 0.54 for the whole basin. The shade data were used to verify USLE model.

Table 5: Soil erosion amount of USLE output and Observed sediment yield for accuracy evaluation. 


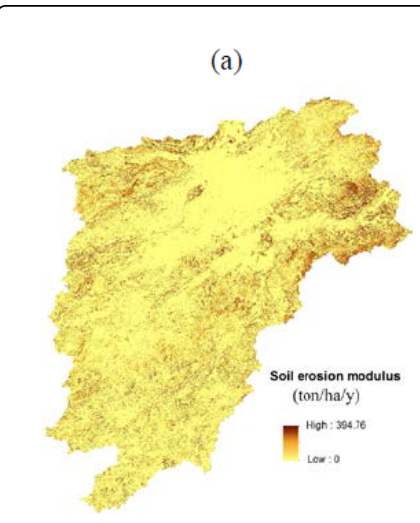

(b)

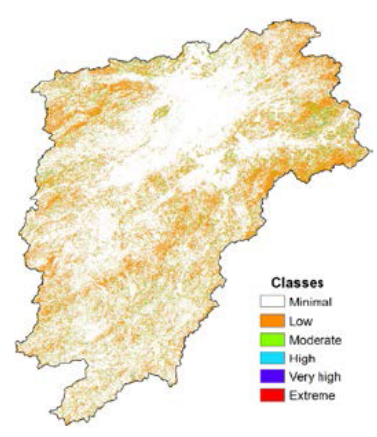

Figure 3: Soil loss in the Poyang Lake basin. (a) annual soil erosion modulus; (b) classes of soil erosion intensity.

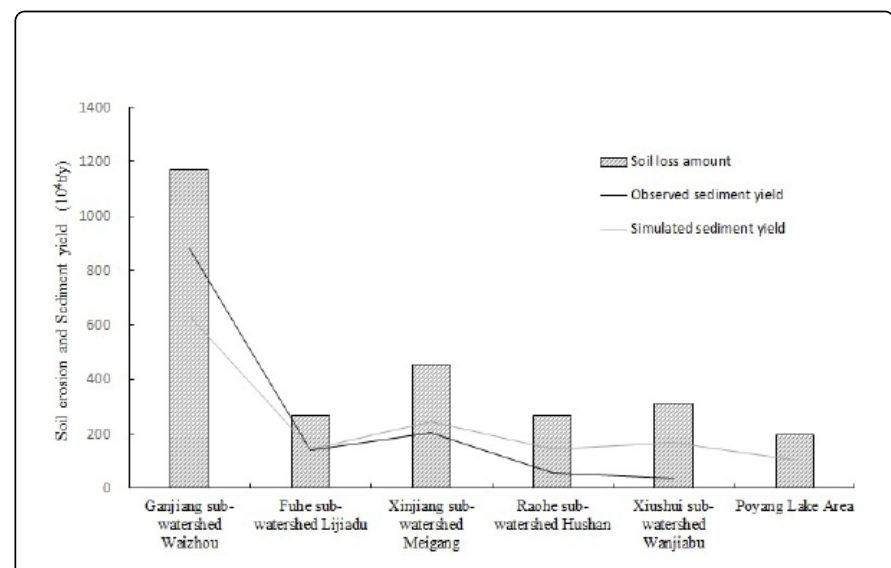

Figure 4: Soil erosion and sediment yield in each sub-watershed.

From the perspective of sub-watershed (Figure 5 and Table 5), the largest mean soil erosion modulus occurred at Xinjiang sub-watershed, reaching $2.91 \mathrm{t} / \mathrm{ha} / \mathrm{y}$; the amount of soil loss is $452 \times 10^{4} \mathrm{t} / \mathrm{y}$, accounting for $17.0 \%$ of the total amount of soil loss (Figure 5(b)); sediment yield is $244 \times 10^{4} \mathrm{t} / \mathrm{y}$ at Xinjiang sub-watershed. The second largest mean soil erosion modulus occurred at Xiushui sub-watershed, reaching $2.16 \mathrm{t} / \mathrm{ha} / \mathrm{y}$; the amount of soil loss is $312 \times 10^{4} \mathrm{t} / \mathrm{y}$, accounting for $11.7 \%$ of the total amount of soil loss (Figure $5(\mathrm{~b})$ ); sediment yield is $169 \times 10^{4} \mathrm{t} / \mathrm{y}$ at Xiushui sub-watershed. The largest amount of soil loss occurred at Ganjiang sub-watershed, reaching 1168 $\times 10^{4} \mathrm{t} / \mathrm{y}$, accounting for $43.9 \%$ of the total amount of soil loss (Figure $5(\mathrm{~b})$ ), and sediment yield is $631 \times 10^{4} \mathrm{t} / \mathrm{y}$; but its soil erosion modulus is only $1.44 \mathrm{t} / \mathrm{ha} / \mathrm{y}$. For Fuhe sub-watershed, Raohe sub-watershed and Poyang lake area, their mean soil erosion modulus is $1.69,1.78$ and 0.96 , respectively; the amount of soil erosion and sediment yield is 267 $\times 10^{4} \mathrm{t} / \mathrm{y}$ and $144 \times 10^{4} \mathrm{t} / \mathrm{y}, 265 \times 10^{4} \mathrm{t} / \mathrm{y}$ and $143 \times 10^{4} \mathrm{t} / \mathrm{y}, 198 \times 10^{4}$ $\mathrm{t} / \mathrm{y}$ and $107 \times 10^{4} \mathrm{t} / \mathrm{y}$, respectively; their proportion of the total soil loss is $10.0 \%, 10.0 \%$ and $7.4 \%$ (Figure $5(\mathrm{~b})$ ), respectively.

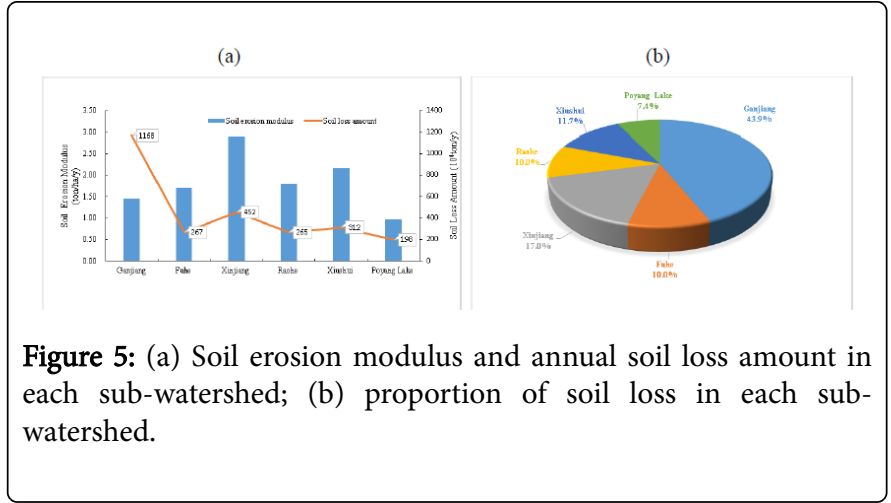

\section{Classification and evaluation of soil erosion intensity}

Based on the average annual soil erosion modulus, the study area was classified into 5 erosion intensity categories (Figure 3(b) and Table 6). The classification was based on the Standard of Classification and Gradation of Soil Erosion, Industry Standard of Water Resource (SL 190-2007), issued by the Ministry of Water Resource of China in 2008. As can be seen in the Table 6, more than $70 \%$ land area was observed to have minimal soil erosion $(71.7 \%)$, where soil erosion modulus is less than $5 \mathrm{t} / \mathrm{ha} / \mathrm{y}$; Minimal soil loss area is $1164.5 \times 10^{4}$ ha, and the amount of annual soil loss is $473 \times 10^{4} \mathrm{t}$, accounting for $17.8 \%$ of the total soil loss in the study area, which were mostly found around the lake area, river valleys and both banks of five main rivers. As the study area are divided into the Red Soil and Hills Erosion Category Area of the Southern China, and soil loss tolerance in this region is $5 \mathrm{t} / \mathrm{ha} / \mathrm{y}$, once more than this figure would be considered as soil erosion; Thus, the minimal soil erosion area in the study is under a soil loss tolerance.

\begin{tabular}{|c|c|c|c|c|c|}
\hline $\begin{array}{l}\text { Erosion } \\
\text { class }\end{array}$ & $\begin{array}{l}\text { Classification } \\
\text { Criteria } \\
\text { (t/ha/y) }\end{array}$ & $\begin{array}{ll}\text { Soil } & \text { loss } \\
\text { area } & \left(10^{4}\right. \\
\text { ha) } & \end{array}$ & $\begin{array}{l}\text { Area } \\
\text { affected } \\
(\%)\end{array}$ & $\begin{array}{l}\text { Annual soil } \\
\text { loss amount } \\
\left(10^{4} t\right)\end{array}$ & $\%$ \\
\hline Minimal & $<5$ & 1164.5 & 71.7 & 473 & 17.8 \\
\hline Low & $5-25$ & 390.2 & 24.1 & 1051 & 39.5 \\
\hline Moderate & $25-50$ & 54.9 & 3.4 & 662 & 24.9 \\
\hline High & $50-80$ & 9 & 0.6 & 266 & 10 \\
\hline Very High & $80-150$ & 2.8 & 0.2 & 155 & 5.8 \\
\hline Extreme & $>150$ & 0.5 & 0 & 55 & 2.1 \\
\hline
\end{tabular}

Table 6: Classes of soil erosion.

In reverse, the soil loss area accounted for $28.3 \%$ of the whole land area, including from low to extreme soil erosion classes. $24.1 \%$ land area was low class soil erosion, primarily found in the west, east, and central hilly and mountains areas, with annual soil loss of $1051 \times 10^{4} \mathrm{t}$, accounting for $39.5 \%$ of the total soil loss in the study area. It is an overriding soil erosion class in the soil loss area. Moderate soil erosion was estimated for $3.4 \%$ of the study area, with annual soil loss of $662 \times$ 10 , accounting for $24.9 \%$ of the total soil loss. Low and moderate class soil erosion are two main categories, and more than $60 \%$ of the total soil loss amount (64.4\%) comes from low and moderate soil erosion. Approximately only $0.8 \%$ of the study, $12.3 \times 10 \mathrm{a}$ land area, was estimated to undergo high, very high and extreme erosion, with annual 
soil loss of $476 \times 10^{4} \mathrm{t}$, accounting for $17.9 \%$ of the total soil erosion amount.

\section{Soil erosion assessment on different landform types}

Landforms play a crucial role in a process of soil erosion. Landforms of the study area were classified into 4 main types by elevation and relative elevation (Table 7 ), such as plains $(53.08 \%)$, hills $(34.04 \%)$, middle mountains (11.57\%) and high mountains (1.31\%). Landform classification standard can be seen in Table 7 . Soil erosion appearing in the plains includes most of minimal erosion (43.45\%), low erosion (7.89\%), moderate erosion (1.40\%) and erosion from high to extreme $(0.33 \%)$. In addition, soil erosion occurring in hills area include minimal erosion $(22.01 \%)$, low erosion $(10.27 \%)$, moderate erosion (1.40\%), and erosion from high to extreme $(0.37 \%)$. Soil erosion in middle mountain area include minimal erosion (5.74\%), low erosion (5.29\%), moderate erosion (0.5\%) and erosion form high to extreme $(0.05 \%)$. Soil erosion proportion in high mountain area is very low at each erosion category. In addition, the mean soil erosion modulus on different landform shows that plains have low soil erosion modulus, only $1.32 \mathrm{t} / \mathrm{ha} / \mathrm{y}$; soil erosion modulus in hills area is $2.21 \mathrm{t} / \mathrm{ha} / \mathrm{y}$; soil erosion modulus in middle mountains is $2.46 \mathrm{t} / \mathrm{ha} / \mathrm{y}$, and soil erosion modulus in high mountains reaches $3.30 \mathrm{t} / \mathrm{ha} / \mathrm{y}$. Plains and hills are most frequently soil loss zone, accounting for $39.3 \%$ and $42.2 \%$ of the total soil loss amount in the basin, respectively. Soil loss amount appearing in middle mountains areas accounted for $16.0 \%$ of the total soil loss amount, and even less (2.4\%) soil loss occurred in high mountain areas.

\begin{tabular}{|c|c|c|c|c|c|c|c|c|c|c|c|}
\hline \multirow[t]{2}{*}{$\begin{array}{l}\text { Landform } \\
\text { type }\end{array}$} & \multirow[t]{2}{*}{$\begin{array}{l}\text { Elevation } \\
\text { (m) }\end{array}$} & \multirow{2}{*}{$\begin{array}{l}\text { Relative } \\
\text { elevation } \\
\text { (m) }\end{array}$} & \multirow{2}{*}{$\begin{array}{l}\text { Soil } \\
\text { erosion } \\
\text { amount } \\
(\%)\end{array}$} & \multirow{2}{*}{$\begin{array}{l}\text { Mean soil } \\
\text { erosion } \\
\text { modulus } \\
(\mathrm{t} / \mathrm{ha} / \mathrm{y})\end{array}$} & \multicolumn{6}{|c|}{ Soil loss area (\%) } & \multirow[t]{2}{*}{$\begin{array}{l}\text { Sum of area per } \\
\text { landform }(\%)\end{array}$} \\
\hline & & & & & Minimal & Low & Moderate & High & $\begin{array}{l}\text { Very } \\
\text { high }\end{array}$ & Extreme & \\
\hline Plains & $<200$ & $<50$ & 39.3 & 1.32 & 43.45 & 7.89 & 1.4 & 0.25 & 0.07 & 0.01 & 53.08 \\
\hline Hills & $200-500$ & $50-200$ & 42.2 & 2.21 & 22.01 & 10.27 & 1.4 & 0.26 & 0.09 & 0.02 & 34.04 \\
\hline $\begin{array}{l}\text { Middle } \\
\text { mountains }\end{array}$ & $500-1000$ & $>200$ & 16 & 2.46 & 5.74 & 5.29 & 0.5 & 0.04 & 0.01 & 0.002 & 11.57 \\
\hline $\begin{array}{l}\text { High } \\
\text { mountains }\end{array}$ & $>1000$ & $>200$ & 2.4 & 3.3 & 0.51 & 0.7 & 0.1 & 0.01 & 0.002 & 0.0004 & 1.31 \\
\hline $\begin{array}{l}\text { Sum of area } \\
\text { per erosion } \\
\text { class (\%) }\end{array}$ & & & - & - & 71.7 & 24.14 & 3.4 & 0.56 & 0.17 & 0.03 & 100 \\
\hline
\end{tabular}

Table 7: Soil erosion assessment on different landform types.

\section{Soil erosion assessment on different LULC types}

As can be seen in Table 8, rainfed croplands, needle leaved forest, broadleaved deciduous forest and shrub land are the main LULC types in the study area, accounting for $29.9 \%, 29.2 \%, 24.4 \%$ and $11.5 \%$ of the total study area, respectively, with annual soil loss of $826 \times 10,897 \times$ $10,106 \times 10^{4} \mathrm{t}$ and $727 \times 10^{4} \mathrm{t}$, respectively; and the proportion of soil loss amount is $31.0 \%, 33.7 \%, 4.0 \%$ and $27.3 \%$, respectively. Thus, rainfed croplands, needle leaved forest and shrub land had the uppermost soil loss amount with large proportion of land area among all LULC types. The amount of soil loss on irrigated croplands, spares vegetation, artificial surface, and water bodies is close or equal to 0 ; and soil loss amount on bare areas is $8 \mathrm{t} / \mathrm{y}$. In addition, soil erosion modulus on different LULC types descend in the order by bare lands, grass lands, shrub lands, rainfed croplands, needle leaved forest, spares vegetation, broadleaved deciduous forest, artificial surface, irrigated croplands, and water bodies.

\begin{tabular}{|l|l|l|l|l|l|}
\hline LULC types & $\begin{array}{l}\text { Area } \\
\left(\mathbf{1 0}^{4} \mathbf{a}\right)\end{array}$ & $\begin{array}{l}\text { Area } \\
(\mathbf{\%})\end{array}$ & $\begin{array}{l}\text { Annual soil } \\
\text { erosion } \\
\text { amount(104) }\end{array}$ & $\begin{array}{l}\text { Soil loss } \\
\text { percent } \\
(\%)\end{array}$ & $\begin{array}{l}\text { Soil } \\
\text { erosion } \\
\text { modulus } \\
(\mathbf{t} / \mathbf{h a} / \mathbf{y})\end{array}$ \\
\hline $\begin{array}{l}\text { Irrigated } \\
\text { croplands }\end{array}$ & 9.92 & 0.6 & 1 & 0 & 0.09 \\
\hline
\end{tabular}

\begin{tabular}{|l|l|l|l|l|l|}
\hline $\begin{array}{l}\text { Rainfed } \\
\text { croplands }\end{array}$ & 484.6 & 29.9 & 826 & 31 & 2.17 \\
\hline $\begin{array}{l}\text { Broadleaved } \\
\text { deciduous } \\
\text { forest }\end{array}$ & 395.63 & 24.4 & 106 & 4 & 0.27 \\
\hline $\begin{array}{l}\text { Needleleave } \\
\text { d forest }\end{array}$ & 473.81 & 29.2 & 897 & 33.7 & 1.89 \\
\hline Shrub lands & 186.82 & 11.5 & 727 & 27.3 & 3.89 \\
\hline Grass lands & 24.14 & 1.5 & 97 & 3.6 & 4.02 \\
\hline $\begin{array}{l}\text { Spares } \\
\text { vegetation }\end{array}$ & 0.01 & 0 & 0 & 0 & 0.92 \\
\hline $\begin{array}{l}\text { Artificial } \\
\text { surface }\end{array}$ & 6.14 & 0.4 & 1 & 0 & 0.15 \\
\hline Bare areas & 0.64 & 0 & 8 & 0.3 & 12.99 \\
\hline $\begin{array}{l}\text { Water } \\
\text { bodies }\end{array}$ & 40.3 & 2.5 & 0 & 0 & 0 \\
\hline
\end{tabular}

Table 8: The amount and area proportion soil erosion on different LULC types. 
Citation: Yuan LF, Yang GS, Zhang QF, Li HP (2016) Soil Erosion Assessment of the Poyang Lake Basin, China: Using USLE, GIS and Remote

Page 9 of 12

Table 9 showed that low erosion mainly come from needle leaved forest (14.71\%), shrub land (5.33\%), and rainfed croplands $(3.65 \%)$; moderate erosion primarily come from shrub land (1.68\%) and rainfed croplands (1.27\%); erosion form high to extreme come from rainfed croplands $(0.66 \%)$, shrub land $(0.08 \%)$ and grass land $(0.01 \%)$. In addition, broadleaved deciduous forest, rainfed croplands, needle leaved forest and shrub land are the main contribution to minimal erosion. Overall, effective soil and water conservation measures should be adopted or strengthen on three LULC types: needle leaved forest, shrub land, and rainfed croplands.

\begin{tabular}{|c|c|c|c|c|c|c|}
\hline \multicolumn{7}{|c|}{ Soil erosion classes (\%) } \\
\hline LULC types & Minimal & Low & Moderate & High & $\begin{array}{l}\text { Very } \\
\text { high }\end{array}$ & $\begin{array}{l}\text { Extrem } \\
\text { e }\end{array}$ \\
\hline Irrigated croplands & 0.61 & 0 & 0 & 0 & 0 & 0 \\
\hline Rainfed croplands & 24.07 & 3.65 & 1.27 & 0.46 & 0.17 & 0.03 \\
\hline $\begin{array}{l}\text { Broadleaved } \\
\text { deciduous forest }\end{array}$ & 24.44 & 0.03 & 0 & 0 & 0 & 0 \\
\hline Needleleaved forest & 14.47 & 14.71 & 0.13 & 0 & 0 & 0 \\
\hline Shrub lands & 4.47 & 5.33 & 1.68 & 0.08 & 0 & 0 \\
\hline Grass lands & 0.77 & 0.41 & 0.3 & 0.01 & 0 & 0 \\
\hline Spares vegetation & 0 & 0 & 0 & 0 & 0 & 0 \\
\hline Artificial surface & 0.37 & 0.01 & 0 & 0 & 0 & 0 \\
\hline Bare areas & 0.02 & 0.01 & 0.01 & 0 & 0 & 0 \\
\hline
\end{tabular}

Water bodies

\begin{tabular}{|l|l|l|l|l|l|}
\hline 2.49 & 0 & 0 & 0 & 0 & 0
\end{tabular}

Table 9: Soil erosion classes assessment on different LULC types.

\section{Sediment loads in main reservoirs of the Poyang Lake basin}

To analyze and evaluate the possible sediment load of the main reservoirs, we listed geographic location of main reservoirs (Figure 6) and their basic information (Table 10), and multiplied the average annual soil loss by SDR to calculate the annual upstream sediment yield of the reservoirs. The SDR used the value suggested by Jing et al [37], the minimum SDR value is 0.5 , the maximum SDR value is 0.9 , and the mean SDR value is 0.7. In addition, we assumed all the sediment would be trapped by the reservoirs, with no sediment moving downstream of it. As can be seen in Table 10 and Figure 7, there are 4 reservoirs whose capacity is larger than $5.0 \times 10^{8} \mathrm{~m}^{3}$, and they are Tuolin, Wan'an, Shangyoujiang and Hongmen, respectively; the mean annual sediment load entering above reservoirs is $171.4 \times 10^{4}$ $\mathrm{t}, 402.2 \times 10^{4} \mathrm{t}, 36.6 \times 10^{4} \mathrm{t}$ and $34.2 \times 10$, respectively; the maximum annual sediment load entering each reservoir reaches $220.3 \times 10^{4} \mathrm{t}$, $517.1 \times 10^{4} \mathrm{t}, 36.6 \times 10$ and $43.9 \times 10^{4} \mathrm{t}$, respectively. Sediment load in the Wan'an reservoir is the largest one among all above reservoirs because of its large upstream drainage area. Other six reservoirs whose capacity ranges from $0.83 \times 10^{8} \mathrm{~m}^{3}$ (Gongchanzhuyi) to $2.76 \times 10^{8} \mathrm{~m}^{3}$ (Da'ao), and upstream sediment yield varies from $2.0 \times 10^{4} \mathrm{t}$ (Gongchanzhuyi) to $8.7 \times 10$ (Qiyi). On average, $677.2 \times 10^{4} \mathrm{t}$ sediment, at least $483.7 \times 10^{4} \mathrm{t}$ and $870.7 \times 10^{4} \mathrm{t}$ at most flow into the above 10 reservoirs yearly. These sediment shorten the life span of reservoirs. On the other side, they decrease sediment flowing downstream into the Poyang Lake.

\begin{tabular}{|c|c|c|c|c|c|c|c|c|c|c|c|c|}
\hline \multirow[t]{2}{*}{ ID } & \multirow[t]{2}{*}{ Name } & \multirow[t]{2}{*}{ Location } & \multirow[t]{2}{*}{ X-cor } & \multirow[t]{2}{*}{ Y-cor } & \multirow[t]{2}{*}{$\begin{array}{l}\text { Construct } \\
\text { Time }\end{array}$} & \multirow{2}{*}{$\begin{array}{l}\text { Reservoir } \\
\text { capacity } \\
\left(10^{8} \mathrm{~m}^{3}\right)\end{array}$} & \multirow{2}{*}{$\begin{array}{l}\text { Upstream } \\
\text { Drainage } \\
\text { Area (ha) }\end{array}$} & \multirow{2}{*}{$\begin{array}{l}\text { Upstream } \\
\text { soil erosion } \\
\text { modulus } \\
(\mathrm{t} / \mathrm{ha} / \mathrm{y})\end{array}$} & \multirow{2}{*}{$\begin{array}{l}\text { Upstream } \\
\text { soil loss } \\
\left(10^{4} \mathrm{t} / \mathrm{y}\right)\end{array}$} & \multicolumn{3}{|c|}{ Sediment yield $\left(10^{4} t / y\right)$} \\
\hline & & & & & & & & & & Min. & Max. & Mean \\
\hline 1 & Tuolin & Xiushui & 115.34 & 29.28 & $1958-1985$ & 50.17 & 941516 & 2.6 & 244.8 & 122.4 & 220.3 & 171.4 \\
\hline 2 & Sheshang & Ganjiang & 114.25 & 27.37 & 1969-1981 & 1.43 & 47326 & 2.05 & 9.7 & 4.9 & 8.7 & 6.8 \\
\hline 3 & Wan'an & Ganjiang & 114.95 & 26.24 & $\begin{array}{l}\text { 1958-1961, } \\
\text { 1978-1996 }\end{array}$ & 11.16 & 3246030 & 1.77 & 574.5 & 287.3 & 517.1 & 402.2 \\
\hline 4 & Shangyoujiang & Ganjiang & 114.35 & 25.83 & $1955-1957$ & 7.21 & & 1.85 & 52.3 & 26.2 & 47.1 & 36.6 \\
\hline 5 & Shangyou & Ganjiang & 115.08 & 28.54 & 1958-1959 & 1.35 & 14781 & 2.4 & 3.5 & 1.8 & 3.2 & 2.5 \\
\hline 6 & Qixing & Xinjiang & 118.34 & 28.16 & $1985-1991$ & 1 & 20810 & 3.1 & 6.5 & 3.2 & 5.8 & 4.5 \\
\hline 7 & Qiyi & Xinjiang & 118.24 & 28.83 & 1958-1960 & 2.49 & 31864 & 3.88 & 12.4 & 6.2 & 11.1 & 8.7 \\
\hline
\end{tabular}

Table 10: The basic information of main reservoirs and simulated annual soil loss and sediment yield in the upstream of each reservoir. 


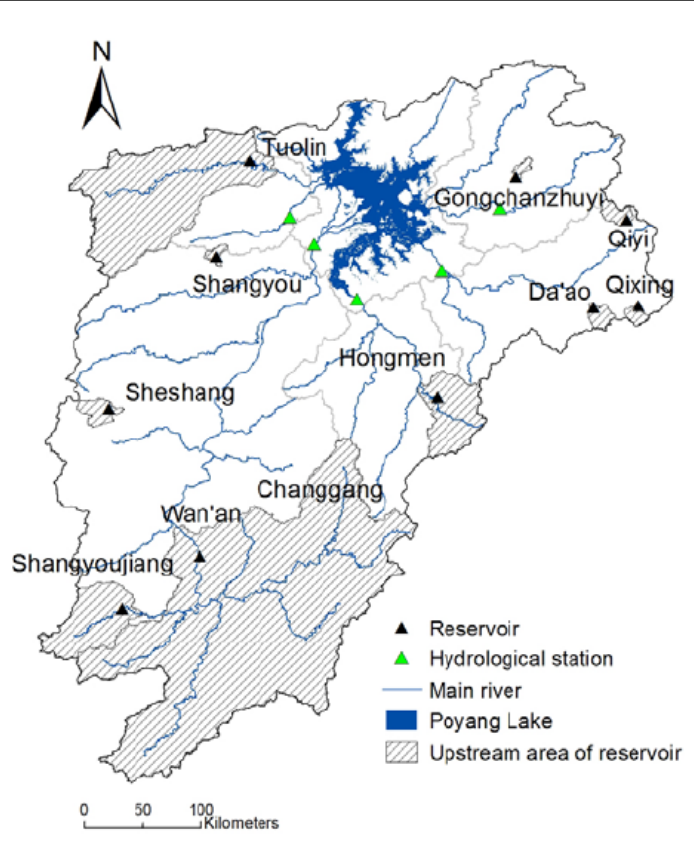

Figure 6: The location and upstream drainage area of the main reservoir.

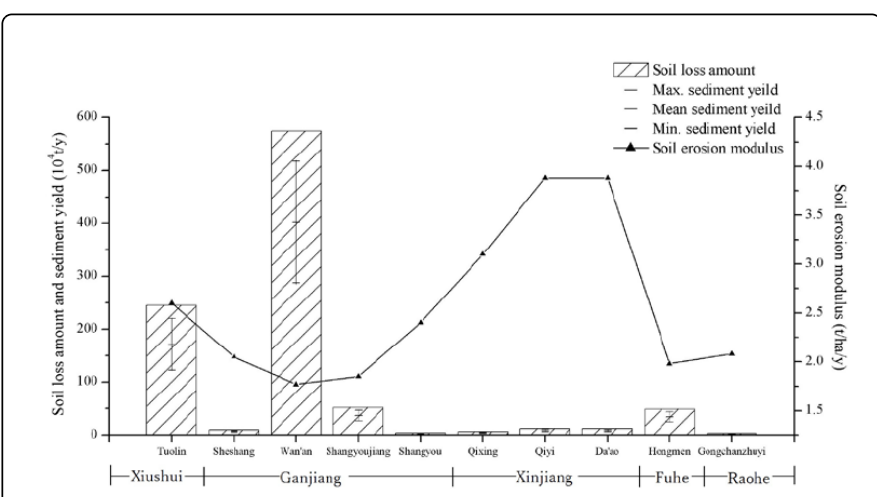

Figure 7: The soil loss amount, soil erosion modulus, the minimum, maximum and mean sediment yield of upstream drainage area of each reservoir.

From the perspective of sub-watershed (Tables 5 and 10), the Tuolin is the largest reservoir in the Poyang Lake basin. Assuming SDR is 0.54, annual sediment load entering this reservoir accounted for $78.2 \%$ of the total sediment yield of the Xiushui sub-watershed. Sediment load entering reservoirs, including Sheshang, Wan'an, Shangyoujiang and Shangyou accounted for $54.8 \%$ of the total sediment yield of the Ganjiang sub-watershed. Three reservoirs, Qixing, Qiyi and Da'ao, can absorb $6.8 \%$ of annual sediment yield of the Xinjiang sub-watershed. The Hongmen is the largest reservoir of the Fuhe sub-watershed, and upstream sediment yield accounted for $18.3 \%$ of sediment of the total sub-watershed. However, sediment load entering the Gongchanzhuyi reservoir only accounts for $1.1 \%$ of the total sediment yield in the Raohe sub-watershed because of its small upstream control area.
In addition, among these mentioned above, of all reservoirs for which the soil erosion modulus on upstream drainage area is larger than $3.0 \mathrm{t} / \mathrm{ha} / \mathrm{y}$, located in Xinjiang sub-watershed, and they are Qiyi (3.88 t/ha/y), Da'ao (3.88 t/ha/y) and Qixing (3.10 t/ha/y), respectively. In addition, soil erosion modulus of upstream of the Tuolin reservoir reach $2.60 \mathrm{t} / \mathrm{ha} / \mathrm{y}$. Thus, above four reservoirs should be more threatened by upstream sediment.

\section{Discussion}

This case study evaluated average annual soil erosion in Poyang Lake basin by using USLE model. The sediment yield was estimated by applying an empirical SDR method. The spatial pattern of soil erosion and its impact on reservoirs were finally evaluated.

The study was largely based on earlier research on soil erosion in the Poyang Lake basin $[12,22,26,28]$. The spatial pattern of average annual soil erosion was generally consistent with the findings of Lu et al. [12], but the amount of annual soil erosion $\left(0.27 \times 10^{8}\right)$ is far less than the results $(1.85 \times 10$ in 2000$)$ of Lu et al. [12] because rainfall erosivity $(R)$ exhibited a significant difference when it was calculated. Furthermore, the amount of soil erosion $(0.12 \times 10)$ in Ganjiang sub-watershed is close to that $\left(0.19 \times 10^{8} \mathrm{t}\right)$ of Jing et al. [37]; However, soil erosion modulus in Ganjiang sub-watershed is $1.44 \mathrm{t} / \mathrm{ha} / \mathrm{y}$ in this study, but the figure is $2.38 \mathrm{t} / \mathrm{ha} / \mathrm{y}$ in Jing et al. [38]. In addition, the total annual sediment load in the Poyang Lake $\left(1438 \times 10^{4} \mathrm{t}\right)$ is close to the results $(1689 \times 10)$ of Min et al. [35].

The upstream sediment yield data are available for only a few reservoirs for the basin. Thus, it was not possible to analyze sediment load of all the reservoirs. So, a few simulated results were compared and analyzed according to the current limited data. Sediment load on the Tuolin reservoir $\left(171.4 \times 10^{4} \mathrm{t}\right)$ is close to that $(155 \times 10)$ of $\mathrm{Li}$ et al. [26], but annual sediment load on Wan'an reservoir $\left(402.2 \times 10^{4} \mathrm{t}\right)$ is less than that $\left(742 \times 10^{4} \mathrm{t}\right)$ of Sun et al. [6]. Certainly, the advantage of the study is that it analyzed not only the current spatial pattern of soil erosion and its impact on sediment transportation at reservoirs, but also the way this relationship is likely to play out in the future when additional reservoirs come into operation in the Poyang Lake basin.

This study had some limitations. Firstly, sediment transport is a very complex process affected by many various spatio-temporal factors. We assessed sediment yield by applying an empirical average SDR value, but obviously this was not accurate. Secondly, we analyzed only sediment load in each reservoir and did not take the varied deposition capacity of the reservoirs into account. Thirdly, there are total 9,782 reservoirs on tributaries of the basin that play an important role in intercepting sediment, but this study did not consider all of them. Finally, the basin is undergoing gully erosion and landslides, but this study focused on regional scale soil erosion of hill slopes, so the data and methods were not appropriate for the analysis of gully erosion and landslides; thus, the assessment of soil loss amount would be less than the actual annual soil loss amount. While this study did not involve gully erosion and landslides, future studies could do so.

\section{Conclusions}

The purposes of the study was to comprehensive analyze soil erosion, its spatial pattern and impact on main reservoirs in the Poyang Lake basin. A quantitative estimation based on GIS and remote sensing was made by using USLE model. The study found below: 
Soil erosion is a serious environmental issue in the basin. The area of soil erosion accounted for $28.3 \%$ of the total land area. Annual soil loss amount reach $2663 \times 10^{4} \mathrm{t} / \mathrm{y}$; the mean soil erosion modulus is $1.82 \mathrm{t} / \mathrm{ha} / \mathrm{y}$; annual sediment flowing into the Poyang Lake is $1436 \times$ $10^{4} \mathrm{t} / \mathrm{y}$.

Soil erosion show an uneven spatial pattern; Xinjiang subwatershed, Xiushui sub-watershed, and the upstream area of the Ganjiang and Fuhe River were found more serious soil erosion.

Low and moderate soil erosion are two main erosion categories, accounting for more than $60 \%$ of the total soil loss amount, and they primarily occurred on needleleaved forest, shrub lands and rainfed lands three LULC types and on plains and hills two landform types.

Main reservoirs are undergoing the threat of upstream sediment, especially reservoirs such as Qiyi, Da'ao, Qixing and Tuolin, because high soil erosion modulus exist in above area.

We conclude that soil erosion is a serious eco-environmental problem in the basin and that effective and appropriate soil and water conservation measures should be adopted as early as possible. This research is important to assist authority in decision making for layout erosion control areas, starting regulation projects, and conduct soil conservation measures.

\section{Acknowledgements}

This work was financially supported by Science Foundation of Key Laboratory of Virtual Geographic Environment (Nanjing Normal University) (Grant: 201GE05), Ministry of Education, China; the National Natural Science Foundation of China (Grant: 41001158, 41171020, 41271500, 41371273), and the National Basic Research Program of China (Grant: 201B417006), and partly sponsored by the Jiangsu Overseas Research \& Training Program for University Prominent Young \& Middle-aged University Teachers and Presidents project.

\section{References}

1. Zhou Q, Yang S, Zhao C, Cai M, Ya L (2014) A Soil Erosion Assessment of the Upper Mekong River in Yunnan Province, China. Mountain Research and Development 34: 36-47.

2. Li Z, Zhu B, Li P (2008) Advancement in study on soil erosion and soil and water conservation. Acta Pedologica Sinica 45: 802-809.

3. Wang Z (2000) Analysis of affecting factors of soil erosion and its harms in China. Transactions of CSAE 16: 32-36.

4. Zheng F, Wang Z, Yang Q (2008) The review and prospect on soil erosion research in China. Chinese Journal of Nature 30: 12-16.

5. Li R, Shangguan Z, Liu B, Zheng F, Yang Q (2009) Advances of soil erosion research during the past 60 years in China. Science of Soil and Water Conservation 7: 1-6.

6. Sun P, Zhang Q, Chen X, Chen Y (2010) Spatio-temporal patterns of sediment and runoff changes in the Poyang lake basin and underlying causes. Acta Geographic Sinica 65: 828-840.

7. Zuo C (1999) The present situation and strategy measurement of water and soil conservation in Jiangxi. Jiangxi Hydraulic Science and Technology 25: 200-203.

8. Shi Z, Zhang T, Gao H (2008) Water and soil loss characteristics in Poyang Lake basin. Journal of Yangtze River Scientific Research Institute 25: 38-41.

9. Zou Y, Zhang Z, Zhou Q, Liu B (2002) Risk assessment of ecoenvironment factors on soil erosion based on GIS. Bulletin of Soil and Water Conservation 22: 48-50.
10. Ma L, Jiang G, Zou C, Qiu G, Huo H (2009) Spatial and temporal distribution characteristics of rainfall erosivity changes in Jiangxi province over more than 50 years. Transactions of the CSAE 25: 61-68.

11. Fan Z, Huang L, Qian H, Fang Y (2009) Soil erosion effects driven by land use changes over the Poyang Lake basin. Resources Science 31: 1787-1792.

12. Lu J (2011) Soil erosion changes based on GIS/RS and USLE in Poyang Lake basin. Transactions of CSAE 27: 337-345.

13. Yuan L, Yang G, Li H, Zhang Z (2013) Study on variation rule of rainfall spatial distribution in Poyang lake basin on Geo-statistic method and GIS. Research of Soil and Water Conservation 20: 34-38.

14. Wischmeier WH, Smith DD (1978) Predicting rainfall erosion losses: a guide to conservation planning. In: USDA. Agriculture Handbook No. 537, Washington DC, USA, pp: 1-67.

15. Flanagan DC, Nearing MA (1995) USDA-Water Erosion Prediction Project: Hillslope Profile and Watershed Model Documentation. NSERL Rep. No. 10. West Lafayette, IN: National Soil Erosion Research Lab, United States Department of Agriculture, USA.

16. Morgan RPC, Quinton JN, Smith RE, Govers G, Poesen JWA, et al. (1998) The European Soil Erosion Model (EUROSEM): A dynamic approach for predicting sediment transport from fields and small catchments. Earth Surface Processes and Landforms 23: 527-544.

17. Shrestha S, Babel MS, Gupta AD, Kazama F (2006) Evaluation of annualized agricultural nonpoint source model for a watershed in the Siwalik Hills of Nepal. Environmental Modelling \& Software 21: 961-975.

18. Arnold JG, Srinivasan R, Muttiah RS, Williams JR (1998) Large area hydrologic modeling and assessment part I: Model development. Journal of the American Water Resources Association 34: 73-89.

19. Lim KJ, Park YS, Engel BA, Kim NW (2011) SATEEC GIS System for Spatiotemporal Analysis of Soil Erosion and Sediment Yield. In: Godone DD ( ${ }^{\mathrm{e}} \mathrm{d}$.), Soil Erosion Studies. InTech.

20. Kumar A, Devi M, Deshmukh B (2014) Integrated Remote Sensing and Geographic Information System based RULSE modeling for estimation of soil loss in western Himalaya, India. Water Resources Management 28: 3307-3317.

21. Lee S (2004) Soil erosion assessment and its verification using the Universal Soil Loss Equation and Geographic Information System: a case study at Boun, Korea. Environmental Geology 45: 457-465.

22. Zhu M (2015) Soil erosion assessment using USLE in the GIS environment: a case study in the Danjiangkou reservoir region, China. Environ Earth Sci 73: 7899-7908.

23. Yuan L (2013) Soil erosion sensitivity assessment for Poyang Lake basin on GIS and USLE. Bulletin of Soil and Water Conservation 33: 196-201.

24. Sun S (2014) On The attribution of the changing hydrological cycle in Poyang Lake Basin, China. Journal of Hydrology 514: 214-225.

25. Yuan L, Yang G, Li H, Zhang Z (2014) Rainfall multiple time scale variation rule of Poyang Lake basin in the past 50 years. Resources and Environment in the Yangtze Basin 23: 434-440.

26. Arnoldus HMJ (1980) An approximation of the rainfall factor in the Universal Soil Loss Equation. Assessment of Erosion, New York, Wiley, pp: 127-132.

27. Li H, Chen X, Lim KJ, Cai X, Sagong M (2010) Assessment of soil erosion and sediment yield in Liao watershed, Jiangxi province, China, using USLE, GIS and RS. Journal of Earth Science 21: 941-953.

28. Pradhan B, Chaudhari A, Adinarayana J, Buchroithner MF (2012) Soil erosion assessment and its correlation with landslide events using remote sensing data and GIS: a case study at Penang Island, Malaysia. Environmental monitoring and assessment 184: 715-727.

29. Yu JX, Zheng BF, Liu YF, Liu CL (2011) Evaluation of soil loss and transportation load of adsorption $\mathrm{N}$ and $\mathrm{P}$ in Poyang Lake watershed. Acta Ecologic Sinica 14: 3980-3989.

30. Moore ID, Burch G (1986) Physical Basis of the Length-Slope Factor in the Universal Soil Loss Equation. Soil Sci. Soc. Amer J 50: 1294-1298.

31. Moore ID, Burch G (1986) Modeling erosion and deposition: topographic effects. Trans of ASAE 29: 1624-1640. 
Citation: Yuan LF, Yang GS, Zhang QF, Li HP (2016) Soil Erosion Assessment of the Poyang Lake Basin, China: Using USLE, GIS and Remote Sensing. J Remote Sensing \& GIS 5: 168. doi:10.4172/2469-4134.1000168

Page 12 of 12

32. Reuter HI, Nelson A, Jarvis A (2008) An evaluation of void filling interpolation methods for SRTM data. International Journal of Geographic Information Science 21: 983-1008.

33. Chatterjee S, Krishna AP, Sharma AP (2014) Geospatial assessment of soil erosion vulnerability at watershed level in some sections of the Upper Subarnarekha river basin, Jharkhand, India. Environ Earth Sci 71 357-374.

34. Erencin Z (2000) C-factor mapping using remote sensing and GIS: a case study of LOM Sak/ Lom Kao, Thailand. International Institute for Aerospace Survey and Earth Sciences (ITC), Holland.

35. Renard KG, Foster GR, Weesies GA (1997) Predicting soil erosion by water: a guide to conservation planning with the revised universal soil loss equation (RUSLE). Agriculture Handbook No. 537.
36. Min Q, Shi J, Min R (2011) Preliminary analysis of the characteristics and changes of suspended sediment in and out the Poyang Lake during 1956-2005. Journal of China Hydrology 31: 54-58.

37. Luo W, Zhang X, Deng Z, Chen L, Gippel CJ (2014) Runoff and sediment load transport and cause analysis in Poyang Lake basin over the period 1956-2008. Advances in Water Science 25: 658-667.

38. Jing K, Jiao J, Li L, Zhang S (2010) Research on soil erosion amount and sediment delivery radio in the hilly red soil region of southern China. Journal of hydraulic Engineering 41: 1476-1482.

39. Jing K, Jiao J, Li L, Zhang S (2010) The scale relationship of sediment discharge, erosion amount and sediment delivery ratio in drainage basin: a case study in the Ganjiang River basin. Geographical Research 29: $1163-1170$. 